\title{
Marshal louis Nicolas devout in the historiography of the battle of Borodino
}

\author{
Francesco Rubini* \\ Academy of Engineering, Peoples' Friendship University of Russia, School of Historical Studies, \\ Higher School of Economics, Moscow, Russian Federation
}

\begin{abstract}
This article is dedicated to the study and analysis of the historiography about the participation of Marshal Davout during the Battle of Borodino of 1812. The article analyzes a number of sources of both personal and non-personal nature and the effect of the event on art. In the work are offered by the author professional translations of several extracts of historiography which have never been translated from Russian, and which are therefore still mostly unknown to the international scientific community. In addition, the article provides some statistical data on the opinion of contemporaries on the results of the Patriotic War of 1812.
\end{abstract}

\section{Introduction}

«Скажи-ка, дядя, ведь не даром

Москва, спаленная пожаром,

Франиузу отдана?

Ведь были ж схватки боевые,

Да, говорят, еще какие!

Недаром помнит вся Россия

Про день Бородина!»
"Hey tell, old man, had we a cause When Moscow, razed by fire, once was

Given up to Frenchman's blow?

Old-timers talk about some frays,

And they remember well those days!

With cause all Russia fashions lays

About Borodino!».

The battle of Borodino, which took place during the Russian Campaign of 1812, is without any doubt one of the most important and crucial events of Russian history. Fought on the 7th of September, it was a huge large-scale military confrontation between the armed forces of the First French Empire and its allies, led by Napoleon Bonaparte himself, and the Russian Army, commanded by General Mikhail Kutuzov, and is still studied as one of the bloodiest and most ferocious battles of the Napoleonic Wars. Besides, notwithstanding the fact that on that day only two belligerent parties met, on the battlefield was displaced the colossal number of almost 250.000 men and 1.200 field guns in total, and the number of casualties at the end of it was astonishing for that time.

This massive event is so deeply radicated in Russia's culture that even in our times is still remembered with the term "Great Patriotic War of 1812".

In fact, it is important to consider that there is also another "Great Patriotic War", much closer to the period we live in today, that of 1941-1945, and this particular expression

\footnotetext{
* Corresponding author: francesco.rubini@mail.ru
} 
explains very much about the significance of these two challenges the Russian people found itself to overcome.

In addition, even now, more than 200 years later, this event remains resonant both in the historical scientific community and among common people. This can be clearly perceived in the widespread emphasis and importance transmitted in any Russian school to pupils about the events of the war of 1812, in the constant observance of traditional cultural manifestations, and in the speeches politicians, professors, and journalists dedicate to this recurrence every year.

Special interest deserves the influence this battle had on the literature of that time: an immense number of novels, ballads, tales, and poems were born to chant its memory and the pride tenacity of the Russian nation.

\section{Research methods}

The battle of Borodino occupies a very deep place in historical memory of the Russian people, even for those who have no professional relationship to historical sciences, even though today the opinions on the development and the aftermath of the battle itself sometimes may appear distorted or discordant. Actually, the French consider their victory over the Russian army to be the "official" result of the Battle of Borodino, as they did actually occupy all the key points of the battlefield, driving the defenders off their positions, and forcing them to retreat. In fact, at the Invalides, an inscription dedicated to Borodino, or the battle of the "Moscowa", how the French used to call it, occupies a place among the greatest victories of the French emperor, whose names surround his tomb.

However, in the meantime, from the majority of Russian-speaking people, we can hear the opposite opinion about the results of the battle: the French might have tactically won the fight, but they did not manage to turn the retreat of the Russians into a rout. Having inflicted to the enemy tremendous casualties, Kutuzov's army, very far from being broken, was able to fall back neatly, keeping its morale high and fierce, and maintaining a good cohesion.

These fundamental differences of point of view about this battle, accentuated even by the different linguistic expressions used to indicate it, are of a great actuality, for they remind us how history and memory risk to be easily mistaken. For this reason, the process of an adequate research on the subject, trying to cross the different sources we have at our disposal, deserves particular attention.

The methodological basis for this article is provided by the work by A.G. Tartakovsky «1812 and Russian memoirs. Experience of source study», whose author examines the development of the memoirs of this time, and tries to select and reconstruct the complex material about the war of 1812. Nevertheless, the purpose of the analysis of this topic requires a good knowledge of historiography, so that we can try to find out the cause-and-effect relationships of both the formation of mythological views on the course of events at the battle of Borodino. In addition, we can parallelly try to fill the existing gaps in the total number of sources related to this issue; the comparative method and the method of historicism, for instance, allow us to compare much evidence and statistical data, and then to come to a plausible conclusion about how events actually developed.

In this work, the aim is to provide an analysis of the particular figure of Marshal Louis Nicolas Davout in the historiography about this topic, having been one of the most important and active commanders on the battlefield, at the head of the right French wing. 


\section{Results}

As we know, the Duke of Auerstedt was not only a prominent military figure for his time; originally, he belonged to a noble family, whose history began many centuries before. $\mathrm{He}$ had an excellent military education, having graduated from both Brienne-le-Chateau and the École Militaire of Paris, like Napoleon himself. As he was born in 1770, he also saw the breaking out of the French Revolution when he was still young. The new political ideas of this period captured him, and this, among other things, became a catalyst for his further military achievements.

Davout found himself under the command of Napoleon Bonaparte for the first time during the Campaign of Egypt, thanks to his friendship with General Desaix, who personally recommended him. Afterwards, the Corsican general would keep him under great consideration, so great that his career took off considerably in a few years, culminating then in 1804 with the proclamation of the First French Empire, and becoming one of the first marshals of France.

The "Iron Marshal" was a key participant in the military actions of almost all Napoleonic battles, usually occupying the right wing, the"place d'honneur". Among the army corps he commanded we remember the III, which glorified itself during the campaign against Prussia of 1806. In the battle of Auerstedt, the French marshal demonstrated brilliant tactical resourcefulness and tenacity; his troops, alone, despite being severely outnumbered by two to one, managed to not only stop, but even defeat the main Prussian army on the road to Berlin, conferring to Napoleon an overwhelming victory over Frederick William III.

The other famous corps led by Davout was the I, a sixty-six-thousand-strong army, at whose head he crossed the Niemen that 23rd of June 1812 to start the French invasion of Russia.

Of those 66.000 men, after the main battles of Mogilev, Smolensk, Borodino, Krasnyj, Malojaroslavec, Vjaz'ma and Berezina, only a little more than 2.000 would then survive. In more mathematical terms, we can therefore conclude that the I corps, in the period between the 23rd of June and the 29th of November, about five entire months, suffered approximately $97 \%$ of casualties. After the end of the campaign of 1812, the corps formally did not even exist anymore, and was then absorbed by another unit.

Marshal Davout is well known among Russian-speaking readers and researchers. First of all, on the battlefield, as the main opponent of Barclay de Tolly and Bagration, since mostly it was against them that he fought in 1812, but also because of his key roles in the very administration of the occupied territories in Russia. In fact, he was governor in Mogilev and, after the entering of the Grande Armée in Moscow, he was one of the commanders who answered for the order in the city.

After the first months of occupation, by the beginning of autumn, both the Russian and French armies were already exhausted of the constant hostilities they had been waging, as Borodino was only the culmination of a long series of battles and skirmishes on the way towards Moscow. Nevertheless, the French needed a rapid and decisive triumph over the Russians in order to occupy Moscow and conclude the invasion of Russia in a few months, so that they could force the Emperor Alexander I to accept the conditions of Napoleon.

In fact, similar had been the main plan before against the Austrians and the Prussians in the previous years: a lightning-fast overwhelming victory immediately followed by the occupation of the capitals. Notwithstanding these considerations, it is important to remember that Moscow was not the capital of the Russian Empire at that time; it was the second main city of Russia, but still it was considered the spiritual center of the country. 
In this article, we will analyze the testimonies Russian historiography has to offer about the participation of Marshal Davout in this battle, and about the particular place he occupied in Russia's historical memory.

\section{Discussions}

First of all, it is interesting to consider that the historiography on this event involves not only written sources, but also the arts, like painting. Such a curious kind of source ought not to be ignored. In a period with no photography yet, paintings were maybe the only mean to transmit a visual description of battles for those people who had seen none.

The main purpose was to fix on canvas the hugeness of the employed forces, the spectacular effect of hundreds of thousands of soldiers with different uniforms, bright colors, plumes, facial expressions, and emotions. The viewers might stare at them for long hours, in silence, and closing their eyes from time to time, after having memorized a new detail, would try to add and hear in their imagination the beating of the battle drums, the sound of the trumpets, the continuous racket of musketry and artillery fire, and the persistent moaning of wounded, mutilated, or suffering people and horses.

Such effect is able to convey the work "The Battle of Borodino" by F. Roubaud (Figure $1)$.

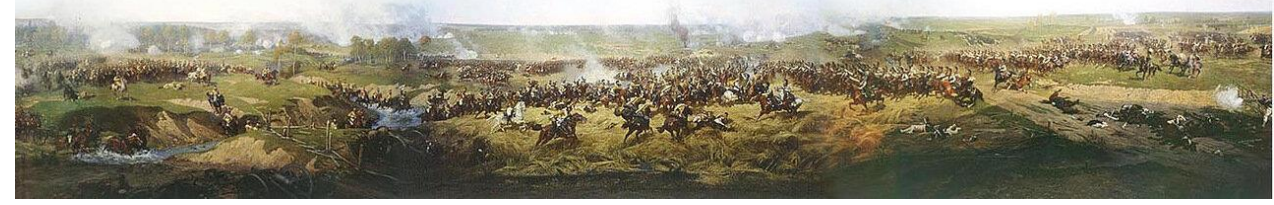

Fig. 1. Franz Roubaud, Borodino Battle Panorama, $115 \mathrm{~m}$ x 15m, oil on canvas, Moscow

This painting is a massive representation of the battle. Its dimensions are impressive: 115 meters of length by 15 meters of height. The main subject of the picture is one of the most critical moments of the fight: encouraged after having captured the Bagration flèches, the French I and III corps, led by marshals Davout and Ney, are trying to break into the Russian formation by attacking simultaneously two fortified points of the enemy, the village of Semjonovskaja and the Kurgan battery. The combat line of the fighting armies in this very moment stretches across the Semjonovskij creek, on the eastern bank of which Russian troops are being pursued after having withdrawn from the flèches.

Prince Bagration has just been wounded by French shrapnel, and his wound would reveal lethal soon afterwards. Russian troops are actively defending their positions, often entering into dire hand-to-hand combat with the French with cold steel and bayonets.

The ferocity of the fights is astonishing. The battle of Borodino is no more the theater of unexpected and brilliant maneuvers, which before might allow Napoleon to win alone against two or three opponents at the same time, and greatly outnumbered, counting only on his genius and his valiant marshals; it is not Ulm, nor Austerlitz or Jena.

War was slowly changing: by that time, armies had become much bigger than they used to be before, and modern technologies were in condition to fasten the production and delivering of arms and supplies. That battle of the 7th of September 1812 was mostly a clash of brute force and direct, repeated and sometimes desperate frontal attacks, which then resulted in unthinkable numbers of dead and wounded for that time.

The really interesting factor for modern historians is how the Russian army could keep its morale and willing to fight high without routing, having suffered almost $40 \%$ of losses. 
This very fact explains the importance of using the word "Patriotic" in the name of the war with the French of 1812.

Of course, written evidence is much more interesting for modern researchers. The historiography on Marshal Davout's participation during the Battle of Borodino is rather vast, since a lot of evidence has survived up to our days from both the French and Russian sides.

Today we can cross their information and analyze them carefully, objectively, and using modern research methods.

"Many of those who fought dropped their weapons, grappled with each other, tore at each other's mouths, strangled one another in close embraces, and fell together, dead. The darted over the corpses, as if on a cobblestone floor, squeezing the corpses into the bloodsoaked earth. More than a thousand cannons, on both sides, sparkled with shots, from which the earth trembled for several versts. A terrible sight then represented the battlefield».

This is only one of the many testimonies, which are quite common both among the Russian and French armies. In this case, we have mostly to work with sources of personal origin, as today we have access to diaries and various memoirs. Russian-language evidence deserves special attention, as its majority is still unknown to the western researcher, for they have never been translated. Several are those about Marshal Davout.

Fyodor Mikhailovich Glinka was a veteran of the Patriotic War of 1812, and he left excellent evidence of a number of events that he managed to report about the battle.

"Marshal Davout, who was supposed to hit the extremity of our left wing, put the divisions of Compans, Dessaix and Friant between Shevardino and the forest, which stretches all the way to Utitsa».

And again:

«Still farther, further to the left, are displaced the divisions of Dessaix and Compans, of the I corps of Marshal Davout. These divisions fought against the troops of Prince Bagration and are fighting at the edge of the woods. They rely on the III corps of Ney, standing against the troops of Borozdin».

And again:

"Davout and Ney had the order to storm the three redoubts, to the viceroy were left Borodino and the large lunette* ${ }^{*}$

(*The Great Redoubt)

And again:

«Davout (went) through the forest. Two huge batteries moved forward to position to open fire on the redoubts. Marshals Davout and Ney are fighting at these trenches. The heads of their columns sometimes show themselves, then hide in the forest, not enduring our firing. Finally, the attack on the redoubts begins: the French run in between to capture them from the rear».

Such historiographical evidence, perhaps, is less colorful than the animated descriptions of fallen soldiers and the shocking death of commanders; however, they are extremely interesting because they provide substantive data on the movement of troops and corps, in particular, of Marshal Davout. This is an extremely valuable information for reconstructing a series of events, for both military history and even military tactics.

Moving on to the French heritage, we are of course interested in the works of Louis Davout himself. In addition to the fact that the marshal wrote his personal diaries, he also sent his own reports on the campaign of 1812 for printing to the Parisian newspaper "Journal de Paris", which then published reports on the activities of both the marshal himself and the Grande Armée in general on Russian territory. A similar source is also represented by the Bulletins of the Great Army, which, being the official periodical of the army, also transmitted up-to-date information about events at the front about the current situation. Among the published materials, there are reports, in particular those that belong to Davout himself. It can be noted that a certain neutrality underlines the content of what is written in the bulletins. 
This is due to the fact that such behavior contributes to the formation of the correct image of the French army in the eyes of other soldiers and compatriots, and also maintains high their morale and faith in the power of both Napoleon and his marshals.

About the memoirs, they were written rather soon after the end of military operations; therefore, they are distinguished by a relative freshness of views and an impeccable perception of time. Davout's memories, like many other sources analyzed in this article, are available online; paradoxically, even if it might seem bizarre in 2021, have never been translated into Russian. By far, one of the most known texts about the Russian campaign of 1812 are the memoires of Philippe-Paul de Segur, brigadier general of Napoleon's staff: his work was translated into Russian, and boasted a good popularity in the XIX century. His descriptions appear well structured, sometimes even colorful. In addition, they may be considered the most striking personal records of a French general officer about the war of 1812, and about the actions of the Napoleonic army on the territory of Russia. Of course, since they are memories of personal nature, they deserved aimed attention in order not to accept too easily the author's personal prejudices and impressions, opinions, and several considerations on the events in which he participated. On the other hand, even if popular belief tends to forget about it, commanders and marshals are human beings too, with emotions and a mind of their own; therefore, such a position in his personal memoirs is more than understandable. Moreover, as a Frenchman, he has the full right to reason and philosophize the way he does about experiences, relationships, and about this enemy, the Russian, whom he so gallantly respected. Philippe-Paul de Segur and his memoirs are a unique historical heritage. Among the quotes related to the events of Davout and the Battle of Borodino, we recollect the following:

«One of Davout's regiments, looking for his place in the first line, got lost in the dark and went further, into the very middle of the Russian cuirassiers, who attacked him and, taking to flight, took away three guns, captured and killed up to three hundred people. The remnant closed in a shapeless mass, bristling with bayonets and surrounded by fire. The enemy could no longer penetrate further into this mass, and the weakened army returned to its place in the battle formation».

Such evidence is very interesting, since it provides direct information about the location of the corps and the leadership of Davout.

And again:

"Rapp was the first to approach him, but in that moment a bullet reached him. This was his twenty-second wound. The third general, who took his place, also fell. Davout was also injured. Rapp was taken to the emperor, who said to him: "How, Rapp, again? What on earth are they doing up there?».

The adjutant answered him that the guard had to be sent in to make it over with the redoubt. "No, - objected Napoleon - I don't want her to be exterminated, I shall win the battle without her"”.

And again:

"Then Ney with his three divisions, which had reduced to 10.000 people, pushed up to the plain. He was hurrying to support Davout. [...] Ney rushed there. The 57th regiment of Compans, having felt the support, was inspired and, making a last effort, reached the enemy trenches, climbed them and, attacking with bayonets, pushed the Russians back and exterminated the most stubborn ones; the remaining routed, and the 57th regiment displaced on the defeated redoubt. At the same time Ney, with the same excitement, rushed to the other redoubts and took them away from the enemy».

And again:

"The battle ended on the plain and concentrated on the remaining enemy heights and against the Great Redoubt, which Barclay stubbornly defended with the help of the center and of the right flank against Prince Eugene. So, around noon, the entire right French wing, 
Ney, Davout and Murat, having overturned Bagration and half of the Russian battle line, turned to the slightly open combat flank of the rest of the enemy army, the interior of which was now visible to them along with its reserves, left without rear cover, right up to the line of retreat».

And again:

«During these mental and physical sufferings, which the emperor tried to hide from his army, Davout penetrated to him in order to offer him himself, even if wounded, as the commander of the vanguard, promising him that he would be able to walk day and night, reach the enemy and force him to take battle, without wasting unnecessarily, like Murat, the strength and life of his soldiers! But Napoleon answered him only by praising the inexhaustible courage and boldness of Murat».

Such interesting personal testimonies offer an idea not only about the course of the events, but also about the very character and personality of these commanders: what they thought about, how they decided to dare taking the initiative, and how they criticized and expressed their divergences with each other.

After all, this chapter of the author's memoirs is called "The Battle on the Moscow River" (La Bataille de la Moskowa), which allows us to pay attention also to the interesting use of the chosen terms and names, as we said before. In this case, this is how the French call the Battle of Borodino.

\section{Conclusion}

In this article, we have highlighted only a few works, and tried to cross their information, without mentioning many others, for it is extremely difficult to dedicate historical attention to all the sources produced on a precise topic. Nevertheless, valuable milestones of Russian historiography, like the works of Egorov and Chinjakov still deserve great attention, especially from the international research community, as their interesting texts have not been translated yet from Russian.

Nevertheless, this work highlights key testimonies about the participation of Marshal Davout during this huge battle, thanks to which we can reconstruct the main maneuvers of the French right wing, and outlines the position his character occupies in both French and Russian historiography. We also consider important to underline that we offered a brief analysis of a source of artistic nature as well, which is a sector too rarely examined for historical analytical purposes, but which doubtless deserves further interest and research.

\section{References}

1. G. Cerino Badone, "I have no army anymore!"

2. Tales of the Wars; or Naval and Military Chronicle (London, 1866)

3. A.R. Andreev, "The battle of Borodino of the 26th of August"

4. F.N. Glinka, from the notes about the year 1812

5. P.P. De Segur, The Campaign of Russia

6. A.I. Egorov, Napoleon's Marshals (Rostov-on-Don, 1998)

7. M.J. Lermontov, Borodino (1837)

8. A.I. Popov, The unknown about the known (Samara, 2017)

9. A.G. Tartakovskij, The year 1812 and Russian memoirs. Experience of source study (Leningrad, 1980)

10. M.K. Chinkakov, Marshal Davout in the Great Patriotic War of 1812 (Moscow, 1999) 